\title{
Z DALEKIEGO WSCHODU NA BLISKI WSCHÓD, DO AFRYKI PÓLNOCNEJ I EUROPY

\author{
POLACY Z MANDŻURII W SZEREGACH WOJSKA POLSKIEGO \\ W LATACH 1939-1945 (II)
}

Ogromnym poświęceniem i odwagą w walce o wolną Polskę wykazywali się również nasi rodacy, którzy w czasie ataku Niemiec hitlerowskich oraz Związku Sowieckiego na Polskę we wrześniu 1939 r. od urodzenia przebywali w Mandżurii ${ }^{1}$. Dramatyczne wiadomości o sytuacji w ojczyźnie nie tylko spowodowały wzrost nastrojów patriotycznych, ale przede wszystkim dały impuls do konkretnych działań2. Tym sposobem już w listopadzie 1939 r. zorganizowano wysyłkę paczek żywnościowych i odzieżowych dla żołnierzy Wojska Polskiego internowanych na terenie Litwy, Łotwy i Rumunii, a nawet jeńców wojennych przebywających w obozach w Niemczech ${ }^{3}$. Co więcej, prawie cała dorosła młodzież polska, w liczbie ponad stu osób, zgłosiła się do polskiego konsulatu w tym mieście, deklarując chęć wy-

Mgr Mariusz Borysiewicz - Instytut Historii i Politologii na Wydziale Filologiczno-Historycznym Akademii Pomorskiej w Słupsku, e-mail: mariuszbory@wp.pl. ORCID: https://orcid.org/00000002-8207-557X.

${ }^{1}$ Już od końca XIX wieku głównym miejscem osiedlania się Polaków na Dalekim Wschodzie stała się Mandżuria, gdzie polscy emigranci budowali koleje oraz stanowili - przynajmniej początkowo - uprzywilejowaną grupę społeczną, będąc często prężnymi przedsiębiorcami, zamożnymi i wykształconymi pracownikami wykwalifikowanymi bądź należąc do miejscowej inteligencji. Polonia skupiająca się w Mandżurii prowadziła też aktywną działalność oświatowo-wychowawczą, organizacyjną i kulturalno-wydawniczą, co przyczyniło się do powstania licznego grona Polaków gotowych do walki w obronie swojej odległej ojczyzny. Ich patriotyzm wynikał z ofiarnej pracy polskiego duchowieństwa, jak i świeckich organizacji polonijnych. Największą z nich było Stowarzyszenie „Gospoda Polska”, przy której rozwinęły się drobniejsze organizacje (J. KNOPEK, Przemiany zbiorowości polonijnych w Azji, „Dzieje Najnowsze” 32(2000), z. 1, s. 205-206).

2 Na podstawie Stowarzyszenia „Gospoda Polska” w obrębie lokalnego skupiska Polaków powstało kilka komitetów niesienia pomocy ofiarom wojny w Polsce. Do akcji pomocowej przyłączyli się nawet drobni przedsiębiorcy i właściciele przydomowych warsztatów, którzy uczestniczyli w zbiórkach na cele narodowe (Książnica Pomorska [dalej: KP], Zbiory Specjalne [dalej: ZS], sygn. 3402, W dalekiej Mandżurii polskość trwa, „Dziennik Polski” 1941, nr 388, k. 55).

${ }^{3}$ B.Z. Wojas, Dzieje Polonii harbińskiej, „Zeszyty Historyczne” [Paryż] 1974, nr 30(250), s. 3-15; A. KosiśsKa, Udziat Polonii harbińskiej w drugiej wojnie światowej, w: Chiny w oczach Po- 
jazdu do Polski lub innego państwa, w którym możliwe byłoby przyłączenie się do polskich oddziałów wojskowych ${ }^{4}$. Podobnie zachował się także Jan Zanoziński, attaché konsulatu w Harbinie, przybyły tu 1 kwietnia 1939 r., który w liście z 15 września 1939 r. do ambasadora Rzeczypospolitej w Tokio prosił o udzielenie mu urlopu bezpłatnego i zezwolenie na wyjazd w charakterze ochotnika. Wstępnie wyrażono zgodę na jego wyjazd i przyznano mu urlop bezpłatny w lutym $1940 \mathrm{r}^{5}$ Ostatecznie jednak bezpłatny urlop otrzymał z dniem 20 kwietnia $1940 \mathrm{r}^{6}{ }^{6}$

We wrześniu 1939 r. na ochotnika do armii polskiej we Francji zgłosił się również Romuald Dramiński, który w harbińskim konsulacie pełnił obowiązki referenta paszportowego od 1 stycznia 1938 r. $^{7}$ Przed przyjazdem do Harbina pracowal w tym samym charakterze w polskim konsulacie w Czerniowcach, które w latach 1918-1940 należały do Rumunii. Dodatkowo przez ponad dwa lata aktywnie działał w Stowarzyszeniu „Gospoda Polska”. Z dniem 30 kwietnia 1940 r. udzielono mu bezpłatnego urlopu, aby mógł udać się do Szanghaju, skąd wraz z innymi Polakami wyruszył do armii polskiej we Francji ${ }^{8}$. Wysiłek Polonii harbińskiej ${ }^{9}$ jest

laków. Księga jubileuszowa z okazji 60-lecia nawiązania stosunków dyplomatycznych między Polska a Chińska Republika Ludową, Gdańsk 2010, s. 119.

${ }^{4}$ Warto pamiętać, że ówczesna kolonia polska w Harbinie znajdowała się w nadzwyczaj trudnych i ograniczających jej rozwój warunkach miejscowych. Emigracja rosyjska, która w porozumieniu z Japończykami opanowała częściowo miejski aparat administracyjny, oraz polityka wewnętrzna lokalnych władz pozostająca pod wpływem niemieckim, nie sprzyjały otwartej manifestacji uczuć patriotycznych. Decyzja o formowaniu się oddziałów polskich poza granicami Polski dotarła do Harbina za pośrednictwem Poselstwa Polskiego w Szanghaju, które otrzymało ją od ambasadora RP w Waszyngtonie w dniu 12 września 1939 r. Ochotnicy mieli być wysyłani do specjalnych ośrodków szkoleniowych na koszt państwa. Wiadomość ta wywołała entuzjazm wśród miejscowych Polaków. Konsulat w Harbinie przeprowadził werbunek ochotników, uzgadniając te działania z Ambasadą RP w Tokio. Ostatecznie komisja lekarska uznała za zdolnych do służby wojskowej 70 mężczyzn niemających żadnych obowiązków rodzinnych, młodych i pełnych zapału do walki (Archiwum Instytutu Hoovera Uniwersytetu Stanforda [dalej: AIH], Ministerstwo Spraw Zagranicznych [dalej: MSZ], sygn. 209, List szyfrowy nr 12 konsula Jerzego Litewskiego w Harbinie z dnia 6 listopada 1939 r.).

${ }^{5}$ AIH, MSZ, sygn. 218, Telegram szyfrowy nr 581/2 od Augusta Zaleskiego do Konsulatu RP w Harbinie z dnia 2 lutego $1940 \mathrm{r}$.

${ }^{6}$ M. Cabanowski, Tajemnice Mandżurii. Polacy w Harbinie, Warszawa 1993, s. 92.

${ }^{7}$ Archiwum Akt Nowych [dalej: AAN], Konsulat Generalny RP w Charbinie [dalej: KGRP], sygn. 14, Telegram Biura Personalnego Ministerstwa Spraw Zagranicznych do Konsulatu RP w Harbinie z dnia 5 stycznia $1938 \mathrm{r}$.

8 AAN, KGRP, sygn. 14, Pismo Konsulatu RP w Harbinie do Ministerstwa Spraw Zagranicznych w Angers z dnia 11 kwietnia 1940 r.; AIH, MSZ, sygn. 218, Telegram szyfrowy Konsulatu RP w Harbinie do MSZ z dnia 14 marca 1940 r.

${ }^{9}$ Na wieść, że we Francji tworzy się Wojsko Polskie pod dowództwem gen. Władysława Sikorskiego, prawie cała młodzież polska w Harbinie (łącznie nawet 200 osób) zgłosiła się do Konsulatu RP, wpisując się na listy ochotników na wyjazd do tworzącego się wojska. Uważano, iż Polskie Siły 
o tyle ważny, że w tamtym czasie w mieście przebywało mniej więcej tysiąc Polaków ${ }^{10}$. Tak więc, gdyby w takiej samej proporcji nastąpił napływ Polaków ze Stanów Zjednoczonych, to należałoby się spodziewać około 500 tys. ochotników ${ }^{11}$.

Tabela 1. Polscy ochotnicy z Mandżurii zaangażowani w walkę o wyzwolenie Polski

\begin{tabular}{|r|l|c|l|}
\hline \multicolumn{1}{|c|}{ Lp. } & \multicolumn{1}{|c|}{ Imię i nazwisko } & $\begin{array}{c}\text { Rok } \\
\text { urodzenia }\end{array}$ & \multicolumn{1}{|c|}{ Odznaczenia } \\
\hline 1. & Henryk Bujnowicz & 1910 & Krzyż Walecznych i Kawaler Virtuti Militari \\
\hline 2. & Borys Dąbrowski & 1921 & Krzyż Walecznych i Kawaler Virtuti Militari \\
\hline 3. & Romuald Dramiński & 1896 & brak \\
\hline 4. & Stanisław Drożdż & 1922 & Krzyż Walecznych i Kawaler Virtuti Militari \\
\hline 5. & Antoni Kajdewicz & 1921 & 4 Krzyże Walecznych \\
\hline 6. & Władysław Karnacewicz & 1920 & brak \\
\hline 7. & Jan Kluczyński & 1921 & brak \\
\hline 8. & Walenty Kuczyński & 1913 & Krzyż Walecznych \\
\hline 9. & Stanisław Lejman & 1907 & Krzyż Zasługi \\
\hline 10. & Piotr Leśniewski & 1915 & Krzyż Zasługi \\
\hline 11. & Wincenty Tomaszewski & 1912 & 2 Krzyże Walecznych i Kawaler Virtuti \\
& & & Militari \\
\hline 12. & Andrzej Zalewski & 1910 & Krzyż Zasługi \\
\hline 13. & Jan Zanoziński & 1905 & brak \\
\hline 14. & Olgierd Żydowicz & 1919 & brak \\
\hline
\end{tabular}

Źródło: E. KAJDAŃSKI, Wspomnienia z mojej Atlantydy, Kraków 2013, s. 273.

Już w pierwszych dniach października 1939 r. walki w Polsce ustały i wysyłka ochotników bezpośrednio do kraju stała się nierealna. Po ewakuacji rządu polskiego do Francji postanowiono, że tam udadzą się ochotnicy z Mandżurii. Wysłanie dużej grupy okazało się niemożliwe, ponieważ Mandżuria od 1932 r. znajdowała się pod całkowitą kontrolą Japonii, która z kolei była sojusznikiem III Rzeszy. Dodatkowo wiązały się z tym duże koszty transportu drogą morską do Francji12. Ostatecznie,

Zbrojne są gwarantem odzyskania niepodległości i reprezentują polską państwowość. Wśród ochotników były także osoby starsze i kobiety (W. Tomaszewski, Harbińczycy w SBSK, „Ułan Karpacki” 1983, nr 97, za: M. Cabanowski, Tajemnice Mandżurii. Polacy w Harbinie, s. 133).

10 J. ZANOZIŃSKI, Harbińczycy w szeregach brygady, w: Samodzielna Brygada Strzelców Karpackich, red. G. Korczyński, Kraków 2014, s. 259.

${ }^{11}$ M. Kaluski, Polska - Chiny 1246-1996, Warszawa 2004, s. 139.

12 Wyjazd grupy czternastu ochotników z Harbina był przede wszystkim zasługą ostatniego konsula RP w Harbine, Jerzego Litewskiego (1891-1980), dzięki któremu udało się pokonać duże trudności natury formalnej i materialnej, tak że w kwietniu 1940 r. ustalono ostatecznie nazwiska osób, stanowiących ochotników z Dalekiego Wschodu (J. ZANOzIŃsKI, Harbińczycy w szeregach brygady, 
dzięki pieniądzom zebranym wśród polskiej diaspory w Harbinie, wysłano czternastu ochotników, na czele z attaché konsulatu, Janem Zanozińskim ${ }^{13}$. Grupa ta w kwietniu 1940 r. udała się potajemnie do Szanghaju, skąd miała trafić do Marsylii.

Przeciętna wieku „Harbińczyków”, jak ich nazywano później w Samodzielnej Brygadzie Strzelców Karpackich ${ }^{14}$, wynosiła 26 lat. Jednak zdecydowanie zawyżał ją najstarszy z nich, czterdziestoczteroletni urzędnik konsularny, a więc Romuald Dramiński. Skład ilościowy grupy ochotników zapewniał w miarę dyskretny wyjazd z terytorium Mandżukuo ${ }^{15}$. Na pytania Japończyków o cel podróży odpowiadano, że jadą w poszukiwaniu pracy lub na studia. Niewątpliwie wychowanie w duchu wartości patriotycznych, na co szczególny nacisk kładli polscy nauczyciele, księża, przedstawiciele konsulatu oraz licznych organizacji społecznych w Harbinie, przełożyło się na decyzję najmłodszych uczestników wyprawy o wstąpieniu do Wojska Polskiego w momencie wybuchu II wojny światowej.

Francuski statek o nazwie „Félix Roussel” z polskimi ochotnikami na pokładzie wypłynął z Szanghaju 8 maja 1940 r. Zanim dopłynął do Marsylii, Niemcy

s. 260). Jerzy Bogumił Litewski pełnił szereg funkcji w polskiej służbie zagranicznej, w tym pracownika konsulatu generalnego Rzeczypospolitej Polskiej w Stambule (1933-1936), również kierownika tamtejszej placówki wywiadowczej „Ghazi”, attaché do spraw handlowych ambasady w Ankarze (1936-1937), praktykanta w Ministerstwie Spraw Zagranicznych (1937-1938), a w końcu konsula w Harbinie (1938-1941). Po wojnie osiedlił się w Sydney, gdzie pochowano go w 1980 r. („Manchuria. A Semi-monthly Publication of the Manchuria Daily News" 1938, t. 4, s. 904-905; W. Skóra, Placówki MSZ Drugiej Rzeczypospolitej w Harbinie w latach 1920-1941 na tle dziejów Chin i Mandżuri (Mandżukuo). Szkic do problemu, w: Na szlakach dwóch światów. Studia ofiarowane Profesorowi Jerzemu Hauzińskiemu w 45-lecie pracy naukowej i dydaktycznej, red. A. Teterycz-Puzio, Słupsk 2016, s. 699).

13 J. Bielatowicz, Zarys dziejów Samodzielnej Brygady Strzelców Karpackich, w: Samodzielna Brygada Strzelców Karpackich, s. 87.

${ }^{14}$ K. GrzyBowsKi, Oblicze Brygady Karpackiej, w: Samodzielna Brygada Strzelców Karpackich, s. 198.

15 Mandżukuo było marionetkowym państwem utworzonym przez Japonię w 1932 r. na terytorium dawnej Mandżurii. Państwem oficjalnie rządził Puyi (1906-1967), od 1932 r. jako prezydent, a od 1934 r. jako cesarz. Był on ostatnim cesarzem Chin zmuszonym do abdykacji w 1912 r. Rzeczywiste rządy w cesarstwie Mandżukuo sprawowały japońskie władze wojskowe, które przekształciły terytorium Mandżurii w ważną bazę zaopatrzeniową dla wojsk japońskich walczących podczas II wojny światowej w Chinach i Azji Południowo-Wschodniej. Upadek cesarstwa nastąpił w wyniku ofensywy Armii Czerwonej w dniu 8 sierpnia 1945 r. Miejsce Japończyków krótkotrwale zajęli Rosjanie, a następnie obszar ten ponownie trafił w ręce Chińczyków kierowanych przez Mao Zedonga. Obecnie są to tereny Chin północno-wschodnich, a więc prowincje Heilongjiang, Jilin i Liaoning (National Archives and Records Administration, Truman Administration, 1945-1946, sygn. 48792682, Telegram od ambasadora Stanów Zjednoczonych w Moskwie Averella Harrimana do prezydenta Harry'ego Trumana i sekretarza stanu James'a Byrnesa z dnia 9 sierpnia 1945 r.; M. KaŁuski, Polacy w rosyjskiej Mandżurii, „Studia Polonijne” 22(2001), s. 109). 
napadły na Francję, a do wojny po stronie państw Osi przystąpiły Włochy ${ }^{16}$. Polacy zeszli na ląd w Port Saidzie na terenie Egiptu i zmuszeni byli czekać na dalsze rozkazy. Miejscowe władze angielskie proponowały Polakom wcielenie do armii brytyjskiej, na co nie wyrażono zgody, gdyż celem ochotników było przede wszystkim wstąpienie w szeregi Wojska Polskiego. Korzystając z pobytu w Port Saidzie, Jan Zanoziński udał się do polskiej ambasady w Kairze celem powiadomienia o przybyciu grupy ochotników z Harbina i uzyskania poleceń odnośnie dalszego postępowania w związku z zaistniałą sytuacją po kapitulacji Francji ${ }^{17}$.

Następnego dnia okazało się, że w Syrii powstają polskie oddziały, do których ochotnicy mają się zgłosić. Tego samego dnia kapitan powiadomił, że statek udaje się do Bejrutu, w pobliżu którego znajdowały się polskie jednostki wojskowe. Po dotarciu do Bejrutu francuskie władze wojskowe przewiozły ochotników do polskiego obozu przejściowego, gdzie po załatwieniu formalności zostali poddani badaniom medycznym i po kilku dniach otrzymali przydział do Brygady Strzelców Karpackich pod dowództwem gen. Stanisława Kopańskiego, stacjonującej w miejscowości Homs w Syrii, do której zgłosili się 17 czerwca 1940 roku $^{18}$. Cała grupa, z wyjątkiem Romualda Dramińskiego i Jana Zanozińskiego, składała się z osób urodzonych w Mandżurii, z których jedynie Walenty Kuczyński ${ }^{19}$ oraz Andrzej Zalewski znali Polskę, gdzie przebywali przez pewien czas na studiach ${ }^{20}$. Co ciekawe, nie tylko część ochotników z Mandżurii nigdy nie widziała kraju swoich przodków, za który przyszło im walczyć w nowo utworzonej jednostce. Można było tam znaleźć między innymi ochotników narodowości żydowskiej, Rusinów czy też rekrutów polskiego pochodzenia $\mathrm{z}$ Teheranu ${ }^{21}$.

${ }^{16}$ M. Cabanowski, Tajemnice Mandżurii. Polacy w Harbinie, Warszawa: Muzeum Niepodległości, 1993, s. 92.

17 W. Tomaszewski, Harbińczycy w SBSK, s. 134.

18 J. ZANOZIŃSKI, Harbińczycy w szeregach brygady, s. 262.

19 Walenty Kuczyński (ur. 9 stycznia 1913 r. w Harbinie, zm. 31 sierpnia 1990 r. w Londynie) był absolwentem Centralnego Instytutu Wychowania Fizycznego w Warszawie, wykładowcą Gimnazjum im. Henryka Sienkiewicza w Harbinie, tobrukczykiem, porucznikiem łączności 2. Korpusu w 3. Karpackim Baonie Łączności, odznaczonym między innymi Złotym Krzyżem Zasługi z Mieczami, Gwiazdą Afryki, a także Gwiazdą Italii. Ojciec Walentego, Jan Kuczyński, był synem zesłanego na Syberię powstańca styczniowego. Pracował jako inżynier kolejowy na linii Kolei Wschodniochińskiej, którą zbudowali Rosjanie przy wydatnej pomocy polskich specjalistów (K. GrodzISKA, Polskie groby na cmentarzach Londynu, t. 2, Kraków 2001, s. 384; A. Grochowski, Tobrukczyk z Harbina. Wspomnienie o Walentym Kuczyńskim, w: Losy pedagogów polskich na Wschodzie, red. E. Walewander, Warszawa 2002, s. 141).

${ }^{20}$ M. Kaluski, Polacy w Chinach, Warszawa 2001, s. 181.

${ }^{21}$ Z. Kоткоwsкi, Na kontynencie afrykańskim. Oddziat Stużby Transportowej S.B.S.K. i głosy na drogach brygady. W 30-a rocznicę (1942-1972) zakończenia dziatań bojowych Samodzielnej Brygady Strzelców Karpackich (S.B.S.K.) w Afryce Pótnocnej, Londyn 1972, s. 87-88. 
W Homs polscy rekruci z Mandżurii spotkali mjr. Aleksandra Kwiatkowskie$\mathrm{go}^{22}$, byłego konsula w Harbinie, który był oficerem łącznikowym między gen. Kopańskim a szefem misji brytyjskiej przy Brygadzie mjr. Sholto-Douglasem ${ }^{23}$. Poza tym przez całą wojnę był on bliskim współpracownikiem gen. Kopańskiego. Kiedy w czasie walk w Afryce zaszła potrzeba oddelegowania do twierdzy Tobruk zaufanego oficera łącznikowego, zadanie to otrzymał właśnie mjr Kwiatkowski. Generał Kopański w swoich wspomnieniach wojennych pisał o nim: „[...] zostawiłem w dowództwie twierdzy mjr Kwiatkowskiego, energicznego i dzielnego oficera, porucznika ułanów jazłowieckich z I wojny, który aż z Harbina przyjechał do Bejrutu w chwili przechodzenia Brygady do Palestyny, by zaciągnąć się do wojska"24. Major Aleksander Kwiatkowski od tego czasu był ściśle związany z grupą harbińczyków, szczególnie przy okazji regularnych spotkań z gen. Kopańskim.

W pierwszych dniach października 1940 r. Brygada Karpacka ${ }^{25}$ została przerzucona rzutami morskimi, kolejowym i samochodowym do Egiptu pod Aleksandrię. W tamtejszym obozie Brygada przygotowywała się do działań bojowych. Przeszła specjalne szkolenie i ćwiczenia, uzupełniono stany osobowe pododdziałów i zaopatrzenie logistyczne ${ }^{26}$. W ramach uzupełnień i przesunięć kadrowych harbińczycy otrzymali następujące przydziały: Romuald Dramiński do Legii Oficerskiej, Jan Zanoziński do dowództwa Brygady, Walenty Kuczyński i Andrzej Zalewski do łączności, Stanisław Lejman i Piotr Leśniewski do transportu, Wincenty Toma-

${ }^{22}$ Aleksander Kwiatkowski (1894-1980) pełnił obowiązki szefa harbińskiego konsulatu od 1 maja 1933 r. do 31 stycznia 1938 r. Podczas I wojny światowej służył w Legionie Puławskim, walczył więc po stronie Rosji z Niemcami. Po wojnie został zawodowym oficerem Wojska Polskiego (od 13 listopada 1918 r.). Przed zatrudnieniem w MSZ w 1928 r. był majorem korpusu kawalerii, lecz $\mathrm{w}$ istocie pracownikiem wywiadu wojskowego. Do resortu spraw zagranicznych trafił w pierwszej fali przeniesień z wojska do MSZ po przewrocie majowym. Doświadczenie zdobywał w poselstwie polskim w Moskwie, gdzie równocześnie prowadził placówkę wywiadowczą „M.1.”. Brał udział w działaniach Polskich Sił Zbrojnych na Zachodzie, między innymi pod Tobrukiem w 1941 r. Po zakończeniu II wojny światowej zamieszkał w Stanach Zjednoczonych (M. KRuszyŃsKI, Ambasada RP w Moskwie 1921-1939, Warszawa 2010, s. 220-223; W. SkóRA, Placówki MSZ Drugiej Rzeczypospolitej w Harbinie w latach 1920-1941 na tle dziejów Chin i Mandżurii (Mandżukuo). Szkic do problemu, w: Na szlakach dwóch światów, s. 697-698).

${ }^{23}$ „Journal of the Society for Army Historical Research” 2005, t. 83, s. 329.

${ }^{24}$ S. KopaŃSKI, Wspomnienie wojenne 1939-1946, Warszawa 1990, s. 176.

${ }^{25} \mathrm{~W}$ jej skład wchodzili polscy ochotnicy z całego świata. Oprócz harbińczyków znaleźli się tam zbiegowie z obozów jenieckich w Niemczech i garstka uchodźców z Rosji, Polacy z Francji, z republik południowoamerykańskich, z Węgier i Rumunii, Polacy z francuskiej Legii Cudzoziemskiej, a nawet z Syrii i Persji (J. BiElatowicz, Zarys dziejów Samodzielnej Brygady Strzelców Karpackich, s. 86).

${ }^{26}$ J. Bielatowicz, Zarys dziejów Samodzielnej Brygady Strzelców Karpackich, s. 97. 
szewski do oddziału sanitarnego, reszta do różnych plutonów ${ }^{27}$. W sierpniu $1941 \mathrm{r}$. Brygada została przerzucona drogą morską do Tobruku, dając możliwość chwilowego odpoczynku dla części osłabionych jednostek australijskich ${ }^{28}$.

W Tobruku ochotnicy z Harbina wzięli udział w walkach obronnych. Następnie uczestniczyli w bitwie pod Gazalą, która miała miejsce 15 grudnia 1941 r. ${ }^{29}$, a także w zdobyciu Cyrenajki (północno-wschodniej Libii), co nastąpiło dzięki skutecznym działaniom Samodzielnej Brygady Strzelców Karpackich ${ }^{30}$. W natarciu pod Gazalą został ranny pierwszy z harbińczyków, którym był Antoni Kajdewicz. W następstwie tej akcji otrzymał Krzyż Walecznych ${ }^{31}$. Kolejne trzy Krzyże Walecznych dostał po przejściu do lotnictwa. W ramach swojej służby latał między innymi nad powstańczą Warszawą. Jeszcze inny przedstawiciel Polonii harbińskiej, Henryk Bujnowicz, za walki obronne w Tobruku został odznaczony orderem Virtuti Militari. Dekoracji dokonał osobiście gen. Władysław Sikorski. Henryk Bujnowicz zginął bohaterską śmiercią na polu walki we Włoszech pod Ankoną w dniu 9 sierpnia 1944 r. ${ }^{32}$

Tuż po zakończeniu walk pod Gazalą do czternastki harbińczyków dołączył Zygmunt Siwek, były pracownik cukrowni w Aszyche, który na własną rękę wyjechał z Harbina. Początkowo walczył w szeregach francuskiej Legii Cudzoziemskiej na Dalekim Wschodzie, a później wraz z oddziałami Wolnych Francuzów znalazł się w Afryce na Pustyni Zachodniej. Gdy dowiedział się o Brygadzie Karpackiej i harbińczykach w jej składzie, natychmiast uzgodnił z władzami francuskimi przeniesienie w szeregi oddziałów polskich ${ }^{33}$. Jego bohaterską śmierć pod Monte Cassino, dnia 17 maja 1944 roku $^{34}$, opisał Melchior Wańkowicz:

W trzecim plutonie, który zdobywa bunkier, pada zabity jego dowódca ppor. Babiuch. Dowództwo obejmuje kpr. pchor. Siwek. Podrywa pluton do dalszej akcji, lecz trafiony w plecy odłamkiem pocisku moździerza, pada ranny. Sanitariusz Sałamoniuk spieszy z pomocą, której Siwek nie przyjmuje, podrywa się do dalszej walki - pada zemdlony. Teraz dopiero sanitariusz, mimo iż jest widoczny, a pociski padają gęsto, opatruje ran-

27 W. Tomaszewski, Harbińczycy w SBSK, s. 135.

${ }^{28}$ S. KopaŃski, Urywki z pamiętnika, w: Samodzielna Brygada Strzelców Karpackich, s. 20-21.

${ }^{29}$ W. LeITGEBER, It speaks for itself. What British war leaders said about the Polish armed forces, 1939-1946. Selections from communiqués, speeches, messages and press reports, London 1947, s. 73.

30 Polish Government Information Center, Polish Facts and Figures, New York 1944, s. 38; His Majesty's Stationery Office, The Tiger Triumphs. The Story of Three Great Divisions in Italy, London 1946, s. 38.

${ }^{31}$ M. Kaluski, Polacy w Chinach, s. 158.

32 Wykaz polegtych i zmarlych żotnierzy Polskich Sit Zbrojnych na Obczyźnie w latach 19391946, Londyn 1952, s. 171; M. Kaluski, Polska - Chiny 1246-1996, s. 139.

${ }_{33}$ M. Cabanowski, Tajemnice Mandżurii. Polacy w Harbinie, s. 93.

${ }^{34}$ Wykaz polegtych i zmartych żotnierzy Polskich Sit Zbrojnych na Obczyźnie w latach 19391946, Londyn 1952, s. 245. 
nego pchor. Siwka, rozstawia nosze i układa go na nich. Pocisk moździerza pada w sam środek noszy, rozrywając rannego i zabijając sanitariusza. Zginął pchor. Siwek, sławny goniec pustyni, uczestnik walk pod Tobrukiem, nieustraszony żołnierz o Polskę nigdy niewidzianą, do której dążył z dalekiego Harbinu ${ }^{35}$.

Po zakończeniu walk pod Tobrukiem i Gazalą dziesięciu mandżurskich ochotników ze względu na posiadane wykształcenie, czyli wyższe studia oraz matury, zostało skierowanych do szkół podchorążych w południowej Palestynie (dzisiejszym Izraelu) w miejscowości Beit Jirja ${ }^{36}$. Otrzymali oni następujące przydziały: Andrzej Zalewski i Walenty Kuczyński na kurs do szkoły podchorążych łączności, Jan Zanoziński ${ }^{37}$ do szkoły podchorążych artylerii, zaś Wincenty Tomaszewski do szkoły podchorążych kawalerii. Borys Dąbrowski, Stanisław Dróżdż, Jan Kluczyński, Władysław Karnacewicz, Antoni Kajdewicz, Olgierd Żydowicz do szkoły podchorążych piechoty. Po ukończeniu „podchorążówek” część wyjechała do Anglii, inni otrzymali różne przydziały do jednostek na Bliskim Wschodzie. W ten sposób grupa czternastu ochotników z Harbina została rozdzielona. Wincenty Tomaszewski po skończeniu Szkoły Podchorążych Kawalerii został skierowany do Pułku Ułanów Karpackich, w którym przeszedł kampanię włoską, walczył pod Monte Cassino, oraz był dowódcą pocztu sztandarowego Pułku Ułanów Karpackich aż do chwili złożenia go w Muzeum im. gen. Sikorskiego w Londynie ${ }^{38}$.

Pełniący służbę w Samodzielnej Brygadzie Strzelców Karpackich ochotnicy z Mandżurii stanowili zwartą i oddaną grupę przyjaciół ${ }^{39}$. Często inni żołnierze dobrotliwie nazywali ich „Harbińczykami”. Co ciekawe, polscy przybysze z Dalekiego Wschodu, podczas służby we wspomnianej jednostce, dorobili się nawet własnej odznaki, reprodukowanej w Zeszycie Specjalnym nr 1 pisma „Broń i Bar-

35 M. Wańkowicz, Bitwa o Monte Cassino, t. 2, Rzym 1947, s. 255.

36 Ta niewielka osada, licząca w latach dwudziestych i trzydziestych XX wieku od 300 do 600 mieszkańców, została całkowicie zniszczona w wyniku pierwszej wojny izraelsko-arabskiej z lat 1948-1949. Jeszcze w 1945 r. miejscowość była zamieszkana przez 940 Palestyńczyków (J.B. BARRON, Palestine. Report and General Abstracts of the Census of 1922, Jerusalem 1923, s. 8; E. MiLlS, Census of Palestine 1931. Population of Villages, Towns and Administrative Areas, Jerusalem 1932, s. 2; Government of Palestine, Department of Statistics, Village Statistics, April, 1945, Jerusalem 1945, s. 31; W. Khalidi, All That Remains. The Palestinian Villages Occupied and Depopulated by Israel in 1948, Washington 1992, s. 88).

37 Jan Zanoziński był między innymi członkiem obsady 10. baterii szkolnej w Szkole Podchorążych Artylerii Przeciwlotniczej w Beit Jirja na trasie między Gazą a Tel-Awiwem (W. GórsKI, Żotnierskim szlakiem przez Tobruk i Monte Cassino, Warszawa 1992, s. 141).

38 W. TOMASZEWSKI, Harbińczycy w SBSK, s. 136.

39 Zbiory prywatne Jerzego Czajewskiego, List Olgierda Żydowicza do Emilii Czajewskiej, Aleksandria (Egipt) 15 maja $1941 \mathrm{r}$. 
wy", wydanym w Londynie w 1985 r. Była to odznaka Ochotniczego Oddziału z Harbina, czyli prostokątna tabliczka o wymiarach $42 \times 17 \mathrm{~mm}$, wykonana z białego polerowanego metalu. U góry znajdował się orzeł państwowy i napis w języku chińskim „Polska”, poniżej napis po polsku - „Oddział Polski”. Przydzieleni do odmiennych rodzajów broni, jako grupa za specjalną aprobatą gen. Stanisława Kopańskiego, mieli również ułatwioną możliwość organizowania spotkań we własnym gronie, $\mathrm{z}$ czego bardzo chętnie korzystali, organizując w wolnych chwilach wspólne zebrania bądź wycieczki ${ }^{40}$.

Wraz z końcem kampanii libijskiej część ochotników przeszła do służby w Polskich Siłach Powietrznych oraz Marynarce Wojennej w Wielkiej Brytanii. Pozostali walczyli we Włoszech ${ }^{41}$ w ramach II Korpusu gen. Władysława Andersa ${ }^{42}$. Jednak bohaterska postawa zaledwie czternastoosobowej grupy przybyszów z Mandżurii w szeregach Wojska Polskiego była wyjątkowa, o czym świadczą między innymi liczne odznaczenia i wyróżnienia, którymi zostali uhonorowani. Pięciu z nich otrzymało Krzyż Virtuti Militari, a więc Henryk Bujnowicz, Borys Dąbrowski, Stanisław Dróżdż, Zygmunt Siwek i Wincenty Tomaszewski, sześciu - Krzyż Walecznych: Henryk Bujnowicz, Borys Dąbrowski, Stanisław Dróżdż, Antoni Kajdewicz - 4 razy, Walenty Kuczyński, Wincenty Tomaszewski - 2 razy, trzech - Krzyż Zasługi z Mieczami: Stanisław Lejman, Piotr Leśniewski, Andrzej Zalewski. Ponadto ośmiu z nich otrzymało stopnie oficerskie. Natomiast wszyscy, bez wyjątku, „wykazali dużo serca i charakteru w pełnieniu swych żołnierskich obowiązków”"43.

Nie mniej interesujące były losy reprezentantów Polonii mandżurskiej, których wybuch wojny na Pacyfiku zastał w Japonii. Cała grupa Polaków z Harbina, przebywających w grudniu 1941 r. w Kraju Kwitnącej Wiśni, przy czynnym udziale ambasadora Rzeczypospolitej Polskiej w Tokio Tadeusza Romera ${ }^{44}$, wyrwała się stamtąd i służyła Polsce podczas II wojny światowej. Korzystając ze statusu dyplomatycznego przewieziono ich japońskim statkiem pasażerskim „Tatuta Maru” z Jokohamy do Lourenco Marques (obecnie Maputo) w Mozambiku, gdzie w sierp-

40 J. ZANOZIŃSKI, Harbińczycy w szeregach brygady, s. 262.

${ }^{41}$ Jednym z nich był Wincenty Tomaszewski, służący w Pułku Ułanów Karpackich, początkowo będącego częścią 3. Dywizji Strzelców Karpackich (Carpathian Infantry Division), którą utworzono z dniem 3 maja 1942 r. w wyniku połączenia żołnierzy Samodzielnej Brygady Strzelców Karpackich i oddziałów Wojska Polskiego przybyłych z ZSRR (Instytut Polski i Muzeum im. gen. Sikorskiego, Oddziałowe Kroniki i Dzienniki Działan, sygn. C.292, Kronika 3 Dywizji Strzelców Karpackich, 1942-1943, k. 1). Tomaszewski brał udział w kampanii włoskiej jako dowódca Pocztu Sztandarowego Pułku Ułanów Karpackich (W. TomASZEwSKI, Harbińczycy w SBSK, s. 136).

42 J. Neja, Polacy w Mandżurii, „Biuletyn Instytutu Pamięci Narodowej” 2002, nr 3, s. 35.

43 J. ZANOZIŃsKi, Harbińczycy w szeregach brygady, s. 263.

44 M.M. Drozdowski, Ameryka Pólnocna. Studia, t. 2, Warszawa 1978, s. 456. 
niu 1942 r. wymieniono wszystkich harbińczyków na personel japońskich placówek dyplomatycznych ${ }^{45}$. Ta wymiana dyplomatyczna i repatriacja przedwojennych sztabów konsularnych Japonii oraz państw alianckich dotyczyła przede wszystkim brytyjskiego ambasadora, Roberta Craigie, a także członków innych delegacji dyplomatycznych, w tym Polaków, Belgów, Czechosłowaków, Greków, Norwegów czy też Holendrów, a nadto sporej grupy cywilów, łącznie około tysiąca osób ${ }^{46}$.

Wśród owych uciekinierów znalazł się między innymi osiemnastoletni, wspomniany już wcześniej, Marian Grochowski, a także dwudziestodwuletni Mieczysław Zapaśnik z żoną Heleną z domu Tchórzewską. Ponadto Stanisława Tchórzewska, siostra Heleny, znana w Harbinie rzeźbiarka, którą wojna zaskoczyła w trakcie wizyty u rodziny, jak również Bronisław Romer, uczeń gimnazjum harbińskiego, odwiedzający akurat swojego stryja, a więc ambasadora Tadeusza Romera. Z grona harbińczyków, którzy wydostali się z Japonii razem z polskimi dyplomatami, komisja wojskowa zakwalifikowała do służby na froncie Mariana Grochowskiego i Mieczysława Zapaśnika. Natomiast Stanisława Tchórzewska i Anna Komarowa wstąpiły do Pomocniczej Lotniczej Służby Kobiet. Poza tym Helena Zapaśnik znalazła się w szeregach Polskiego Czerwonego Krzyża. Z kolei Bronisław Romer służył w doborowym 10. Pułku Strzelców Konnych, a Grochowski i Zapaśnik w 1. Pułku Artylerii Przeciwpancernej. W walkach pod Falaise (1944) drugi z nich - Zapaśnik został ciężko ranny. W rezultacie nagrodzono go Krzyżem Walecznych. Podobny zaszczyt spotkał Mariana Grochowskiego. Na terenie Normandii walczył także Bronisław Romer. Pod koniec wojny każdy z nich uzyskał stopień oficerski ${ }^{47}$.

Niestety po zakończeniu II wojny światowej, pomimo szczerych chęci ${ }^{48}$, żaden z pozostałych przy życiu ochotników mandżurskich nie zdołał dostać się do wymarzonej Polski, za którą walczyli, lecz której w większości nie znali. Polacy z Dalekiego Wschodu pozostali emigrantami, jednak nie w Mandżurii i rodzinnym Harbinie, do którego też nie mogli już wrócić, ale rozrzuceni po całym świecie, przede

${ }^{45}$ Co ciekawe, 19 stycznia 1943 r. statek ten został przydzielony do przewozu alianckich jeńców wojennych, wśród których przeważali Kanadyjczycy, na trasie z Hongkongu do Nagasaki. Niestety więźniowie byli transportowani w katastroficznych warunkach sanitarnych. Liczba alianckich żołnierzy była bowiem tak duża, że nie istniała fizyczna możliwość zapewnienia im miejsca do położenia się na pokładzie statku. Z tego względu „Tatuta Maru” zyskał miano ,piekielnego statku” (T. BAHNAM, We Shall Suffer There. Hong Kong's Defenders Imprisoned, Hong Kong 2009, s. 112; E. MowBraY TATE, Transpacific Steam. The Story of Steam Navigation from the Pacific Coast of North America to the Far East and the Antipodes, 1867-1941, London 1986, s. 68-69).

46 R. CRAIGIE, Behind the Japanese Mask, London 1945, s. 146-147.

${ }^{47}$ KP, ZS, sygn. 3402, Andrzej Grochowski, Z Japonii do Polskiego Wojska, „Dziennik Polski” 20 stycznia 1987, k. 36.

${ }^{48}$ Zbiory prywatne Jerzego Czajewskiego, List Olgierda Żydowicza do Emilii Czajewskiej, Aleksandria (Egipt) 23 grudnia $1940 \mathrm{r}$. 
wszystkim w Anglii, Kanadzie, Włoszech, Stanach Zjednoczonych i Australiii ${ }^{49}$. Ich historia w Samodzielnej Brygadzie Strzelców Karpackich oraz w innych jednostkach Polskich Sił Zbrojnych na Zachodzie to nie tylko chlubna karta dziejów Polonii mandżurskiej, ale także dziejów oręża polskiego, jak i samego narodu polskiego, który zmuszony był do walki o swoje przetrwanie w nieprzychylnych dla niego dziejach Europy ${ }^{50}$.

Co ciekawe, wybuch wojny początkowo nie wywarł większego wpływu na życie codzienne Polaków w Harbinie i okolicznych miejscowościach. Stało się tak dzięki chwilowemu ochłodzeniu stosunków japońsko-niemieckich, które wynikało z sojuszu niemiecko-sowieckiego. Wskutek tego zarówno ambasada polska w Japonii, jak i konsulat w Harbinie funkcjonowały w dalszym ciągu. Pogorszenie nastąpiło w 1941 r. po wybuchu wojny niemiecko-sowieckiej. W dniu 4 października 1941 r. rząd japoński zerwał stosunki dyplomatyczne z Polską, likwidując ambasadę w Tokio oraz konsulaty honorowe w Jokohamie i Osace ${ }^{51}$. Natomiast konsulat w Harbinie istniał jeszcze ponad dwa miesiące. Zlikwidowano go dopiero po wybuchu wojny japońsko-amerykańskiej, Polska bowiem, jako sygnatariusz Karty Atlantyckiej, była sojusznikiem Stanów Zjednoczonych ${ }^{52}$.

Przed likwidacją harbińskiej placówki dotychczasowy konsul, Jerzy Litewski, podjął działania w celu powołania zastępczego oficjalnego polskiego przedstawicielstwa, będącego w stanie reprezentować interesy lokalnej Polonii w kontaktach z władzami mandżursko-japońskimi. Tym sposobem 15 grudnia 1941 r. powstał Polski Komitet Opiekuńczy, który został uznany 10 stycznia 1942 r. przez władze Mandżukuo za oficjalnego przedstawiciela Polaków ${ }^{53}$. Jednocześnie władze zgodziły się na dalsze funkcjonowanie polonijnych instytucji społecznych i oświatowych ${ }^{54}$.

${ }^{49}$ W. Tomaszewski, Harbińczycy w SBSK, s. 137; M. KALUSKI, Polacy w Chinach, s. 158; J. ZANOZIŃSKI, Harbińczycy w szeregach brygady, s. 263.

${ }^{50}$ M. Kaluski, Polska - Chiny 1246-1996, s. 140.

${ }^{51}$ E. Palasz-Rutkowska, A. Romer, Historia stosunków polsko-japońskich, Warszawa 1996, s. $156-157$.

${ }^{52}$ Kartę Atlantycką podpisali przedstawiciele rządów dziewięciu państw koalicji antyhitlerowskiej, w tym emigracyjnego rządu polskiego, podczas międzynarodowej konferencji w Londynie 24 września 1941 r. (S. STRoŃski, The Atlantic Charter. No territorial guarantees to aggressors, no dictatorships, London 1944, s. 2-3).

53 AAN, Kolonia Polska w Mandżurii [dalej: KPM], sygn. 16, Polski Komitet Opiekuńczy, Protokół nr 1 dotyczący spraw organizacyjnych z dnia 12 stycznia 1942 r.

${ }^{54}$ A. Winiarz, Działalność Polskiego Komitetu Opiekuńczego w Harbinie (1942-1945), „Rocznik Polonijny" 1984-1985, s. 197-198. Wspomniana zgoda jest o tyle ciekawa, iż Japończycy wiedzieli o udziale harbińskich Polaków w walkach z Niemcami. Mimo wszystko ich stosunek do społeczności polskiej w pierwszych latach wojny nie uległ zmianie na gorsze (E. KAJDAŃsKI, Wspomnienia z mojej Atlantydy, Kraków 2013, s. 274). 
Komitet składał się z czterech osób, zaś jego przewodniczącym został Albin Czyżewski, a sekretarzem Aleksander Macedoński ${ }^{55}$.

Polski Komitet Opiekuńczy w Harbinie, dysponując pieniędzmi z dotacji, darów na określone cele, opłat pobieranych za swe działanie wśród członków polskiej enklawy, a także z depozytów, wspierał finansowo Gimnazjum im. Henryka Sienkiewicza, Bursę św. Stanisława Kostki i Polskie Towarzystwo Dobroczynności. Pozwoliło to przetrwać tym instytucjom, ale i tak ostatecznie gimnazjum zostało zamknięte decyzją władz miejskich z 25 grudnia 1943 r. ${ }^{56}$ Początkowo stosunki z lokalną administracją były dobre, jednak Polacy byli szykanowani przez, cieszących się przywilejami ze strony Japończyków, tak zwanych „białych” Rosjan. Rosjanie zmuszali ich do zrzekania się obywatelstwa polskiego i oddawania swoich paszportów. Dodatkowo pozbawiali Polaków pracy zarobkowej i tym samym źródeł utrzymania. W samym Harbinie ograniczali działalność Stowarzyszenia „Gospoda Polska" oraz innych organizacji polonijnych ${ }^{57}$. Na terenie Harbina przeciwstawiał się tym działaniom Polski Komitet Opiekuńczy, ale pozostali Polacy $\mathrm{w}$ regionie byli pozbawieni jakiejkolwiek ochrony.

Wraz z upływem wojny i pogarszaniem się sytuacji Japonii, w coraz trudniejszym położeniu znajdowała się polska enklawa w Mandżurii. W rękach polskich przedsiębiorców, którzy jeszcze na początku lat trzydziestych XX wieku dysponowali ogromnymi koncesjami leśnymi ${ }^{58}$, górniczymi ${ }^{59}$ i zakładami przemysłowymi $^{60}$, pozostawały już tylko drobne warsztaty i sklepy. Tymczasem Japończycy nakładali na Polaków coraz to nowe obciążenia finansowe. Na początku pojawił się podatek na rzecz związków sąsiedzkiej pomocy. Od 1943 r. Polonia płaciła także składki na Mandżurski Czerwony Krzyż, a rok później podatek na rzecz budowy samolotów i na pomoc rannym pilotom japońskim ${ }^{61}$. Poza tym, od lipca 1944 r., Polacy byli zobowiązani do udziału w przymusowym oszczędzaniu, które polegało na tym, że organizacja reprezentująca kolonię polską w rozmowach z Japończykami, czyli Polski Komitet Opiekuńczy, otrzymała pakiet ponad 4 tys. bonów o różnej wartości, a te z kolei musiały być wykupione przez jej pod-

55 B.Z. Wojas, Dzieje Polonii harbińskiej, s. 12.

56 A. Winiarz, Działalność Polskiego Komitetu Opiekuńczego, s. 198-199.

${ }^{57}$ K.Y. Deog, Kolonia polska w Mandżurii 1897-1949, Kraków 2001, s. 64.

${ }^{58}$ K. Grochowski, Polacy na Dalekim Wschodzie, Harbin 1928, s. 192-193.

${ }^{59}$ Centralne Archiwum Wojskowe, Oddział II Sztabu Głównego (Generalnego) z lat 1921-1939, sygn. I.303.4.2015, Odpis przekładu z języka mongolskiego umowy koncesyjnej inż. Kazimierza Grochowskiego zawartej 17 lutego 1916 r., k. 7.

${ }^{60} \mathrm{KP}, \mathrm{ZS}$, sygn. 3392, Wypisy z ksiąg notarialnych z lat 1914-1939, k. 2-12.

${ }^{61}$ J. NeJA, Harbin jako przestrzeń życia i działalności Polonii mandżurskiej, w: Polskie ślady na Dalekim Wschodzie. Polacy w Harbinie, red. A. Furier, Szczecin 2008, s. 67. 
opiecznych $^{62}$. Po zajęciu Mandżurii przez Armię Czerwoną w sierpniu 1945 r. ${ }^{63}$ wszystkie większe fabryki zostały rozebrane i wywiezione w głąb ZSRR. W następnym roku Harbin przejęli Chińczycy, a Polaków pozbawiono resztek mająt$\mathrm{ku}^{64}$. W 1949 r. większość z nich wróciła transportami kolejowymi do Polski, a pozostali - przeważnie najzamożniejsi przedstawiciele diaspory - podzielili los czternastu ochotników i rozproszyli się po całym świecie, wyjeżdżając głównie do Stanów Zjednoczonych i Australii ${ }^{65}$.

\section{BIBLIOGRAFIA}

\section{Źródla archiwalne}

Archiwum Akt Nowych w Warszawie

Kolonia Polska w Mandżurii

Konsulat Generalny RP w Charbinie

Archiwum Instytutu Hoovera Uniwersytetu Stanforda (mikrofilmy przechowywane w Archiwum Akt Nowych w Warszawie)

Ministerstwo Spraw Zagranicznych

Centralne Archiwum Wojskowe w Warszawie

Oddział II Sztabu Głównego (Generalnego) z lat 1921-1939

Instytut Polski i Muzeum im. gen. Sikorskiego w Londynie

Oddziałowe Kroniki i Dzienniki Działań

Książnica Pomorska w Szczecinie

Zbiory specjalne

National Archives and Records Administration at College Park (Narodowe Archiwum Stanów Zjednoczonych w College Park)

Truman Administration, 1945-1946 (Akta administracji prezydenta Trumana z lat 1945-1946)

Zbiory prywatne Jerzego Czajewskiego

\section{Opracowania}

Bahnam T., We Shall Suffer There. Hong Kong's Defenders Imprisoned, Hong Kong: Hong Kong University Press 2009.

BARron J.B., Palestine. Report and General Abstracts of the Census of 1922, Jerusalem: Printed at Greek Convent Press 1923.

${ }^{62}$ AAN, KPM, sygn. 28, Pismo Stowarzyszenia „Gospoda Polska” do Polskiego Komitetu Opiekuńczego, k. 142.

${ }^{63}$ Office of the Assistant Secretary of War, War Department, War Report. Office of Strategic Services (OSS), Washington 1949, s. 457.

${ }^{64}$ J. SzYMAŃsKi, Opieka duszpasterska nad Polakami w Harbinie, „Studia Polonijne” 38(2017), s. 54.

${ }^{65}$ E. KaJdaŃsKI, Wspomnienia z mojej Atlantydy, Kraków 2013, s. 8. 
Bielatowicz J., Zarys dziejów Samodzielnej Brygady Strzelców Karpackich, w: Samodzielna Brygada Strzelców Karpackich, red. G. Korczyński, Kraków: Oficyna Wydawnicza Mireki 2014.

Cabanowski M., Tajemnice Mandżurii. Polacy w Harbinie, Warszawa: Muzeum Niepodległości 1993.

Craigie R., Behind the Japanese Mask, London: Hutchinson and Company 1945.

Deog K.Y., Kolonia polska w Mandżurii 1897-1949, Kraków: PROMO 2001.

Drozdowski M.M., Ameryka Północna. Studia, t. 2, Warszawa: PWN 1978.

Government of Palestine, Department of Statistics, Village Statistics, April, 1945, Jerusalem: Department of Statistics 1945.

GórsKi W., Żołnierskim szlakiem przez Tobruk i Monte Cassino, Warszawa: MPG 1992.

Grochowski A., Tobrukczyk z Harbina. Wspomnienie o Walentym Kuczyńskim, w: Losy pedagogów polskich na Wschodzie, red. E. Walewander, Warszawa: Stowarzyszenie Współpracy Polska-Wschód 2002.

Grochowski K., Polacy na Dalekim Wschodzie, Harbin: Harbin Daily News Press 1928.

Grodziska K., Polskie groby na cmentarzach Londynu, t. 2, Kraków: Polska Akademia Umiejętności 2001.

GrzYBOwski K., Oblicze Brygady Karpackiej, w: Samodzielna Brygada Strzelców Karpackich, red. G. Korczyński, Kraków: Oficyna Wydawnicza Mireki 2014.

His Majesty's Stationery Office, The Tiger Triumphs. The Story of Three Great Divisions in Italy, London: H.M.S.O. 1946.

KAJDAŃSKi E., Wspomnienia z mojej Atlantydy, Kraków: Wydawnictwo Literackie 2013.

KaŁuski M., Polacy w Chinach, Warszawa: Instytut Wydawniczy Pax 2001.

Kaluski M., Polska - Chiny 1246-1996, Warszawa: Verbinum 2004.

Khalidi W., All That Remains. The Palestinian Villages Occupied and Depopulated by Israel in 1948, Washington: Institute for Palestine Studies 1992.

KoPAŃSKi S., Urywki z pamiętnika, w: Samodzielna Brygada Strzelców Karpackich, red. G. Korczyński, Kraków: Oficyna Wydawnicza Mireki 2014.

KopaŃSKi S., Wspomnienia wojenne 1939-1946, Warszawa: Bellona 1990.

Kosińska A., Udział Polonii harbińskiej w drugiej wojnie światowej, w: Chiny w oczach Polaków. Księga jubileuszowa z okazji 60-lecia nawiązania stosunków dyplomatycznych między Polską a Chińską Republiką Ludową, Gdańsk: Wydawnictwo Uniwersytetu Gdańskiego 2010.

KotKowski Z., Na kontynencie afrykańskim. Oddział Służby Transportowej S.B.S.K. i głosy na drogach brygady. W 30-ą rocznicę (1942-1972) zakończenia działań bojowych Samodzielnej Brygady Strzelców Karpackich (S.B.S.K.) w Afryce Północnej, Londyn: Hornsey Printers 1972.

KruszyŃSKi M., Ambasada RP w Moskwie 1921-1939, Warszawa: Instytut Pamięci Narodowej 2010.

LEITGEBER W., It speaks for itself. What British war leaders said about the Polish armed forces, 1939-1946. Selections from communiqués, speeches, messages and press reports, London: Polish Forces, Press Bureau 1947. 
Mills E., Census of Palestine 1931. Population of Villages, Towns and Administrative Areas, Jerusalem: Printed by the Greek Convent and Goldberg Presses 1932.

Mowbray Tate E., Transpacific Steam. The Story of Steam Navigation from the Pacific Coast of North America to the Far East and the Antipodes, 1867-1941, London: Rosemont Publishing and Printing Corporation 1986.

NeJA J., Harbin jako przestrzeń życia i działalności Polonii mandżurskiej, w: Polskie ślady na Dalekim Wschodzie. Polacy w Harbinie, red. A. Furier, Szczecin: Książnica Pomorska im. Stanisława Staszica 2008.

Office of the Assistant Secretary of War, War Department, War Report. Office of Strategic Services (OSS), Washington: United States, War Department 1949.

Palasz-Rutkowska E., Romer A., Historia stosunków polsko-japońskich, Warszawa: Bellona 1996.

Polish Government Information Center, Polish Facts and Figures, New York: Press Office 1944.

SkóRA W., Placówki MSZ Drugiej Rzeczypospolitej w Harbinie w latach 1920-1941 na tle dziejów Chin i Mandżurii (Mandżukuo). Szkic do problemu, w: Na szlakach dwóch światów. Studia ofiarowane Profesorowi Jerzemu Hauzińskiemu w 45-lecie pracy naukowej i dydaktycznej, red. A. Teterycz-Puzio, Słupsk: Akademia Pomorska 2016.

STRoŃSKi S., The Atlantic Charter. No territorial guarantees to aggressors, no dictatorships, London: Hutchinson 1944.

Tomaszewski W., Harbińczycy w SBSK, „Ułan Karpacki” 1983, nr 97, za: M. CABANowsKi, Tajemnice Mandżurii. Polacy w Harbinie, Warszawa: Muzeum Niepodległości 1993.

WaŃKowicz M., Bitwa o Monte Cassino, t. 2, Rzym: Wydawnictwo Oddziału Kultury i Prasy 2 Polskiego Korpusu 1947.

Wykaz poległych i zmarłych żołnierzy Polskich Sił Zbrojnych na Obczyźnie w latach 19391946, Londyn: Instytut Historyczny im. gen. Sikorskiego 1952.

ZANOZIŃSKi J., Harbińczycy w szeregach brygady, w: Samodzielna Brygada Strzelców Karpackich, red. G. Korczyński, Kraków: Oficyna Wydawnicza Mireki 2014.

\section{Czasopisma}

„Journal of the Society for Army Historical Research” 2005, t. 83.

KaŁuski M., Polacy w rosyjskiej Mandżurii, „Studia Polonijne” 22 (2001).

KNOPEK J., Przemiany zbiorowości polonijnych w Azji, „Dzieje Najnowsze” 32 (2000), z. 1.

„Manchuria. A Semi-monthly Publication of the Manchuria Daily News” 1938, t. 4.

NeJa J., Polacy w Mandżurii, „Biuletyn Instytutu Pamięci Narodowej” 2002, nr 3.

SzYMAŃSKi J., Opieka duszpasterska nad Polakami w Harbinie, „Studia Polonijne” 38 (2017).

Winiarz A., Działalność Polskiego Komitetu Opiekuńczego w Harbinie (1942-1945), „Rocznik Polonijny” 1984-1985.

Wojas B.Z., Dzieje Polonii Charbińskiej, „Zeszyty Historyczne” [Paryż] 1974, nr 30 (250). 


\section{Z DALEKIEGO WSCHODU NA BLISKI WSCHÓD, DO AFRYKI PÓŁNOCNEJ I EUROPY}

POLACY Z MANDŻURII W SZEREGACH WOJSKA POLSKIEGO W LATACH 1939-1945 (II)

Streszczenie

Historia Polaków wywodzących się z Mandżurii, którzy brali udział w kampanii wrześniowej, a także w walkach Samodzielnej Brygady Strzelców Karpackich, jak i innych jednostek Polskich Sił Zbrojnych na Zachodzie, to nie tylko niezwykle chlubna karta dziejów Polonii mandżurskiej, lecz również oręża polskiego oraz narodu polskiego walczącego o swoje przetrwanie w szczególnie ciężkich warunkach II wojny światowej. Bohaterska postawa wielu Polaków z Mandżurii walczących w Wojsku Polskim jest tym bardziej godna uwagi, że część z nich znała Polskę wyłącznie z opowiadań swoich rodziców bądź nauczycieli, mimo to po jej upadku w 1939 r. byli oni gotowi do walki o jej wyzwolenie.

Słowa kluczowe: Polonia; Mandżuria; Wojsko Polskie

FROM THE FAR EAST TO THE MIDDLE EAST, NORTH AFRICA, AND EUROPE

POLES FROM MANCHURIA IN THE RANKS OF THE POLISH ARMED FORCES, 1939-1945 (II)

\section{Summary}

The history of Poles originating from Manchuria who participated in the 1939 Defensive War, and in the combat operations of the Independent Carpathian Rifle Brigade, as well as other units of the Polish Armed Forces in the West, is not only a glorious card in the history of Polish diaspora in Manchuria, but it also marks strength of the Polish Army and a nation which was forced to fight for its survival in particularly difficult conditions of World War II. The heroic attitude of many Poles from Manchuria fighting in the Polish Army is all the more remarkable that some of them knew Poland only from the stories told them by their parents or teachers, however after its fall in 1939 they were ready to fight for its liberation.

Keywords: Polish diaspora; Manchuria; Polish Armed Forces 